\title{
PENGARUH LAMA FERMENTASI DAUN PISANG DALAM RANSUM TERHADAP EFISIENSI PENGGUNAAN PAKAN AYAM BROILER
}

\author{
Hengkie Liwe, B. Bagau dan M. R. Imbar
}

Fakultas Peternakan Universitas Sam Ratulangi Manado, 95115

\begin{abstract}
ABSTRAK
Suatu penelitian telah dirancang untuk melihat sejauh mana pengaruh lama fermentasi daun pisang dalam ransum terhadap efisiensi penggunaan pakan ayam broiler. Ternak yang digunakan dalam penelitian adalah 60 ekor ayam broiler galur hubbard yang berumur 3 minggu. Ransum percobaan disusun sebagai berikut $: \mathrm{R}_{0}=$ Ransum dengan daun pisang tanpa fermentasi; $\mathrm{R}_{1}=$ Ransum dengan daun pisang 5 hari fermentasi; $\mathrm{R}_{2}=$ Ransum dengan daun pisang 10 hari fermentasi; $\mathrm{R}_{3}$ = Ransum dengan Daun Pisang 15 hari fermentasi. Penelitian ini dilaksanakan dengan menggunakan rancangan acak lengkap (RAL) yang terdiri dari 4 perlakuan dan 5 ulangan. Analisis yang digunakan untuk mengetahui sejauh mana satu perlakuan berbeda nyata dengan perlakuan lainnya adalah dengan uji BNT. Parameter yang diukur adalah konsumsi ransum, pertambahan berat badan, dan efisiensi penggunaan ransum. Hasil analisis keragamaan menunjukkan bahwa perlakuan memberikan pengaruh yang sangat nyata $(\mathrm{P}<0,01)$ terhadap jumlah konsumsi langsung pertambahan berat
\end{abstract}

badan dan efisiensi penggunaan ransum. Hasil penelitian ini dapat disimpulkan bahwa dengan diperbaikinya nilai nutrisi daun pisang maka penggunaan daun pisang terfermentasi selama 10 hari dalam ransum memberikan pengaruh yang baik terhadap efisiensi penggunaan pakan ayam broiler.

\section{Kata kunci : Daun Pisang, Fermentasi dan Ayam Broiler}

\section{ABSTRACT \\ FERMENTATION PERIOD}

EFFECT OF BANANA LEAF IN RATION ON BROILER FEED EFFICIENCY. This study was done to evaluate the fermentation period effect of banana leaf in ration on broiler feed efficiency. Animals used in this study were sixty broilers (Hubbard strain) at the age of three week old. Research was conducted using completely randomized design involving four treatments with five replications in each treatment. Treatments used were as follows: Ration containing banana leaf without fermentation (R0), Ration containing banana leaf fermented at 
five days (R1), Ration containing banana leaf fermented at ten days (R2), and Ration containing banana leaf fermented at fifteen days (R3). Data were analyzed by variance analysis. Significantly difference treatment effects on variable measures were tested using honestly significant difference (HSD). Variables measured were feed consumption, average daily gain, and feed efficiency. Results showed that that treatments had significantly difference ( $\mathrm{P}<0,01)$ on feed consumption, average daily gain and feed efficiency. It can be concluded that ration containing banana leaf fermented at ten days produce the best feed efficiency of broilers.

Keyword : Fermented banana leaf, feed efficiency, broiler.

\section{PENDAHULUAN}

Pertimbangan bagi suatu jenis bahan makanan yang menjadi pakan temak, bukan hanya terletak pada ketersediaan zat-zat makanan yang diperlukan ternak untuk kebutuhan pokok dan produksi, tetapi sedapat mungkin menghindari terjadinya kompetisi antara kebutuhan ternak dan kebutuhan manusia. Salah satu alternatif yang dapat dilakukan adalah mengupayakan pemanfaatan aneka bahan makanan yang tidak atau kurang bersaing dengan kebutuhan pangan dan secara fisiologi tidak mengganggu kesehatan temak.

Daun pisang merupakan bagian tanaman pisang yang penggunaannya masih terbatas sebagai bahan pembungkus saja. Selain itu tidak atau kurang bersaing dengan kebutuhan manusia, mudah diperoleh dan cukup produksinya atau persediaannya, mempunyai kandungan zat-zat makanan yang tidak bertentangan dengan penerimaan fisiologis unggas dan layak dari segi ekonomis.

Terbatasnya pemanfaatan daun pisang ini disebabkan sifat kimianya yang sulit untuk dicema karena kandungan serat kasar yang tinggi. Peningkatan nilai nutrisi bahan ini, dapat dilakukan dengan proses hidrolisa selulosa secara ensimatik dengan menggunakan mikroorganisme selulolitik.

Trichoderma viride adalah jamur yang memiliki pertumbuhan yang sangat lambat. Jamur ini dikenal sebagai jamur selulolitik yang dalam proses fermentasi dapat menurunkan serat kasar karena dapat menghasilkan enzim ekstraselular yaitu selulose (Hardjo dkk, 1989).

Penerapan bioteknologi pakan melalui proses fermentasi memungkinkan perbaikan kualitas dan kuantitas nutrisi daun pisang. Menurut Winarno dan Fardiaz (1990) bahwa makanan yang mengalami fermentasi mempunyai nilai gizi yang lebih tinggi jika dibandingkan dengan bahan asalnya. Berdasarkan latar 
belakang dan pemikiran tersebut, maka penelitian ini dirancang untuk melihat sejauh mana peningkatan dari daun pisang terfermentasi tersebut diharapkan dapat mempengaruhi efisiensi penggunaan pakan ayam broiler.

\section{MATERI DAN METODE PENELITIAN}

Materi percobaan terdiri dari : (1) Ternak percobaan yaitu ternak yang digunakan pada percobaan ini ialah 60 ekor ayam pedaging jantan galur Hubbard yang berumur 3 (tiga) minggu; (2) Kandang dan perlengkapan yaitu kandang tempat percobaan adalah kandang battery yang terbuat dari bambu sebanyak 20 unit dengan ukuran setiap unit yaitu $40 \mathrm{x} 40 \mathrm{x}$ $45 \mathrm{~cm}$. Dalam setiap unit kandang dipelihara 3 (tiga) ekor ayam, yang dilengkapi dengan tempat makan yang terbuat dari bambu dan tempat minum terbuat dari plastik. Makanan dan air minum diberikan secara ad libitum. Perlengkapan lain yang digunakan adalah ember, kantong plastik, sapu lidi, sekop, karung plastik, kertas koran, perlengkapan listrik, kuas dan sendok untuk mengambil ransum sisa dalam tempat makan;

Tabel 1. Komposisi Daun Pisang Tanpa Fermentasi dan Yang Difermentasi

\begin{tabular}{|c|c|c|c|c|c|}
\hline \multirow{3}{*}{$\begin{array}{l}\text { No } \\
1\end{array}$} & \multirow{3}{*}{$\begin{array}{l}\text { Uraian } \\
\text { Zat Makanan } \\
(\% \text { BK) }\end{array}$} & \multicolumn{4}{|c|}{ Daun Pisang } \\
\hline & & \multirow{2}{*}{$\begin{array}{c}\text { Tanpa } \\
\text { Fermentasi }^{\text {a) }}\end{array}$} & \multicolumn{3}{|c|}{ Fermentasi (hari) b) } \\
\hline & & & 5 & 10 & 15 \\
\hline & Protein Kasar & 9.24 & 11.47 & 13.82 & 14.42 \\
\hline & Lemak & 11.36 & 11.60 & 11.68 & 11.88 \\
\hline & Serat Kasar & 11.74 & 18.40 & 12.70 & 10.22 \\
\hline & BETN & 45.15 & 45.56 & 47.08 & 47.86 \\
\hline & Abu & 15.52 & 12.97 & 14.72 & 15.62 \\
\hline & $\mathrm{Ca}$ & 0.19 & 0.17 & 0.21 & 0.22 \\
\hline & $\mathrm{F}$ & 0.33 & 0.30 & 0.38 & 0.40 \\
\hline 2 & Energi $(\mathrm{kka} / \mathrm{kg})$ & 3810 & 3811 & 3900 & 3915 \\
\hline
\end{tabular}

Keterangan:

a). Hasil Analisa Laboratorium Universitas Sam Ratulangi Manado (1986) dalam Harmain (1986).

b). Hasil Analisa Belai Penelitian dan Pengembangan Industri Manado (1995) 
(3) Jamur, untuk proses fermentasi digunakan mikroorganisme Trichoderma viride yang diperoleh dari koleksi Lembaga Biologi Nasional (LBN) Bogor, dengan ' kode $\mathrm{ABK}_{3}$; (4) Ransum percobaan yaitu bahan-bahan yang digunakan selama percobaan adalah jagung kuning, dedak halus, bungkil kelapa, bungkil kedele, tepung ikan, daun pisang tanpa fermentasi, daun pisang terfermentasi. Komposisi kimia daun pisang, bahan-bahan makanan penyusun ransum perlakuan dan zat-zat makanan tercantum dalam Tabel 1 dan Tabel 2 . Kebutuhan minimal dari zat-zat makanan dapat dipenuhi jika ke dalam setiap ransum percobaan ditambahkan feed supplement "Top Mix" (Tabel 3).

Tabel 2. Komposisi Zat-Zat Makanan dalam Bahan-Bahan Makanan Penyusun Ransum

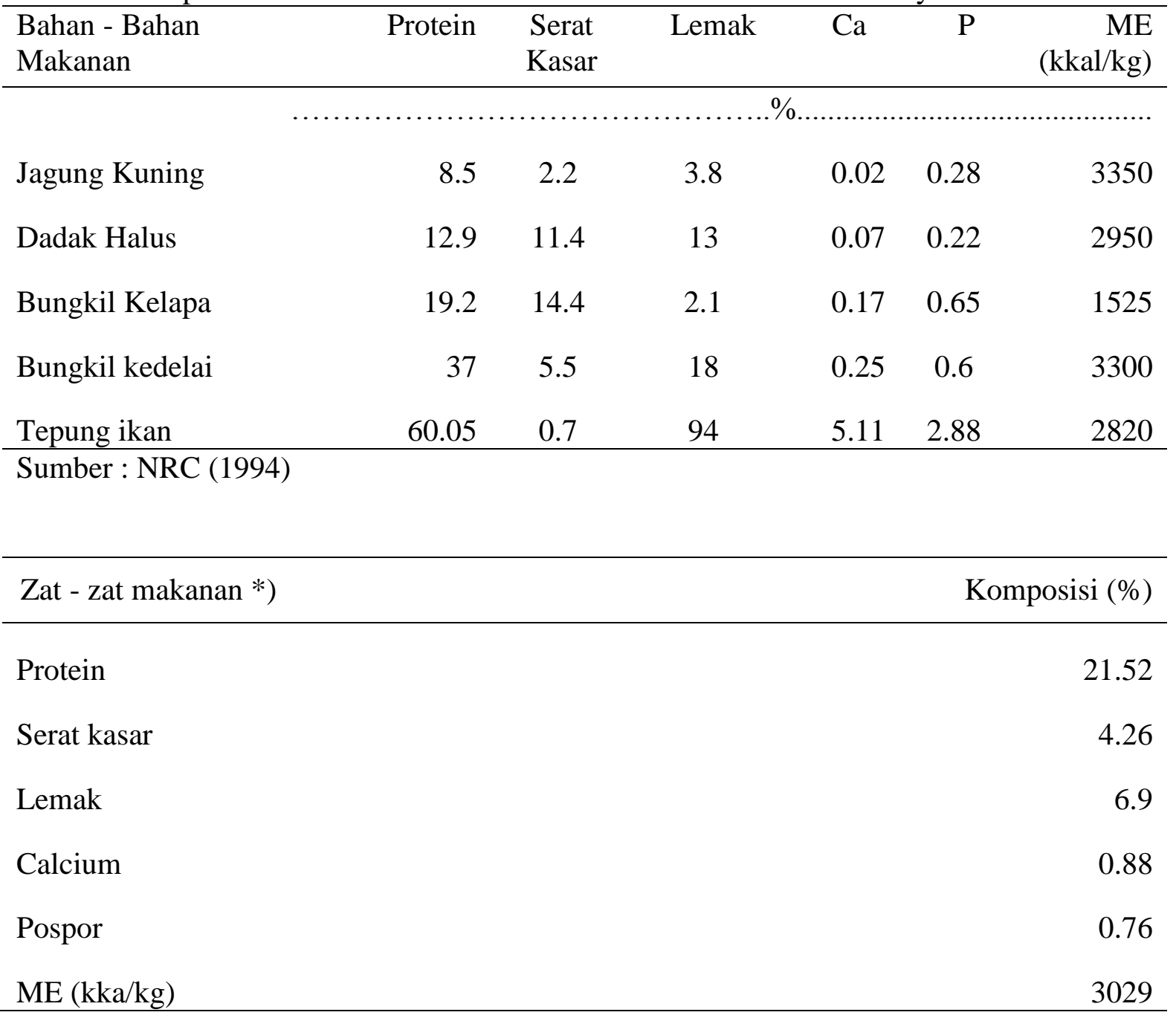

Keterangan:*) Dihitung berdasarkan kandungan zat-zat makanan pada Tabel 2 . 
Tabel 3. Komposisi Bahan dan Kandungan Zat - zat Makanan dari Setiap Jenis Ransum Percobaan

\begin{tabular}{lrrrr}
\hline \multicolumn{1}{c}{ Bahan Bakar } & $\mathrm{R}_{0}$ & $\mathrm{R}_{1}$ & $\mathrm{R}_{2}$ & $\mathrm{R}_{3}$ \\
\hline Jagung Kuning & 54 & 54 & 54 & 54 \\
\hline Dedak halus & 7.5 & 7.5 & 7.5 & 7.5 \\
\hline Bungkil Kelapa & 10 & 10 & 10 & 10 \\
\hline Bungkil Keledai & 12 & 12 & 12 & 12 \\
\hline Tepung Ikan & 16 & 16 & 16 & 16 \\
\hline Top Mix & 0.5 & 0.5 & 0.5 & 0.5 \\
\hline Jumlah & 100 & 100 & 100 & 100 \\
\hline Ransum dasar & 90 & 90 & 90 & 90 \\
\hline Daun Pisang & 10 & 10 & 10 & 10 \\
\hline Zat Makanan *) & & & & \\
\hline Protein & 20.3 & 2051 & 20.75 & 20.81 \\
\hline Serat Lemak & 5.71 & 5.68 & 5.11 & 4.86 \\
\hline Serat Kasar & 7.34 & 7.37 & 7.37 & 7.39 \\
\hline Lemak & 0.96 & 0.94 & 0.98 & 0.98 \\
\hline Calcium Paspor & 0.97 & 0.95 & 1.02 & 1.04 \\
\hline ME (Kkal/kg) & 3031.86 & 3031.84 & 3038.96 & 3040.16 \\
\hline Ketrangan: Dinis
\end{tabular}

Keterangan: *) Dihitung berdasarkan Kandungan makanan pada Tabel 1 dan 2

Penelitian ini dilaksanakan dengan menggunakan rancangan acak lengkap (RAL) yang terdiri dari 4 perlakuan dan 5 ulangan. Penempatan ternak dilakukan secara acak yaitu 3 ekor setiap unit percobaan. Data penelitian dianalisis dengan menggunakan analisis sidik ragam. Tingkat perbedaan dari masing-masing perlakuan diuji dengan menggunakan uji beda nyata terkecil (BNT).

Variabel yang diukur dalam penelitian ini : (a) Konsumsi ransum (gram), dihitung dari selisih antara jumlah ransum yang diberikan dengan ransum sisa setiap hari; (b) Pertambahan berat badan (gram), dihitung dari seiisih antara badan akhir dengan berat badan awal percobaan; (c) Efisiensi Penggunaan Ransum (gram), diperoleh dari perbandingan antara pertambahan berat badan dengan jumlah ransum yang dikonsumsi rata-rata per ekor per hari selama percobaan.

Teknik fermentasi yang digunakan mengikuti prosedur yang dilakukan oleh Lembaga Biologi Nasional (LBN) Bogor, yaitu : (a) Pembuatan suspensi Trichoderma viride, yaitu bahan murni Trichoderma viride dicampur lebih dulu dengan air destilata steril, perbandingan 1 : 9. (b) Mempersiapkan larutan tumbuh yang mengandung komposisi nutrien meliputi 31,25 gram (NH4) ${ }_{2} \mathrm{SO}_{4} ; 6,25$ 
gram $\mathrm{NaH}_{2} \mathrm{P}_{4} ; 0,63$ gram $\mathrm{KC} 1 ; 2,08$ gram . $\mathrm{Mg} ; 0,31$ gram $\mathrm{FeSO}_{4}$ dan 8,35 gram urea dalam 1 liter air destilata; (c) Membuat larutan inokulan yaitu mencampur suspensi Triohoderma viride dengan larutan tumbuh, perbandingan $1: 4$; (d) Daun pisang kering matahari yang telah digiling ditempatkan dalam wadah plastik lalu dibasahi air mendidih (untuk pembasahan dan sterilisasi) kemudian ditiriskan dan didinginkan; (e) Daun pisang yang telah dingin kemudian diinokulasikan dengan larutan inokulan yang mengandung kultur Trichoderma viride dengan takaran inokulan $100 \mathrm{ml}$ inokulan $/ 1 \mathrm{~kg}$ daun pisang. Ketebalan daun pisang dalam wadah plastik yang diinokulasi berkisar $1-3 \mathrm{~cm}$. Selanjutnya diinkubasi selama 5, 10 dan 15 hari pada suhu 23 sampai $28^{\circ} \mathrm{C}$; (f) Setelah waktu fermentasi berakhir, daun pisang terfermentasi dikeringkan dengan sinar matahari kemudian disajikan pada ternak dalam campuran ransum.

\section{HASIL DAN PEMBAHASAN}

Data hasil penelitian tentang pengaruh lama fermentasi daun pisang dalam ransum terhadap konsumsi ransum, pertambahan berat badan, dan efesiensi penggunaan makanan ayam broiler disajikan pada Tabel 4.

Rataan konsumsi ransum per ekor per hari masing-masing perlakuan pada percobaan ini (Tabel 4) berkisar 115.57 125.10 gram. Berarti bahwa rataan konsumsi ransum masih sesuai dengan kisaran konsumsi ransum menurut Scott (1976) yang dilaporkan oleh Wahju (1988), bahwa ayam pedaging yang berumur di atas 5 minggu mengkonsumsi ransum antara 77-135 gram per ekor per hari.

Hasil analisis keragaman menunjukkan bahwa lama fermentasi daun pisang, memberikan pengaruh yang sangat

Tabel 4. Rataan Konsumsi Ransum, Pertambahan Berat Badan, dan Efisiensi Penggunaan Ransum Ayam Broiler

\begin{tabular}{|c|c|c|c|c|}
\hline \multirow{2}{*}{ Parameter yang diukur } & \multicolumn{4}{|c|}{ Perlakuan } \\
\hline & Ro & $\mathrm{Ri}$ & $\mathrm{R} 2$ & $\mathrm{R} 3$ \\
\hline Konsumsi ransum (gr, ekor ${ }^{1}$, hari $\left.{ }^{1}\right)$ & 115.57 & 117.82 & 125.10 & 124.49 \\
\hline Pertambahan berat badan (gr, ekor ${ }^{1}$, hari ${ }^{1}$ ) & 48.50 & 54.25 & 58.03 & 46.15 \\
\hline Efisiensi penggunaan makanan & 0.420 & 0.460 & 0.464 & 0.371 \\
\hline
\end{tabular}


nyata $(\mathrm{P}<0,01)$ terhadap jumlah konsmnsi ransum. Hasil uji lanjut Beda Nyata terkecil menunjukkan bahwa jumlah konsumsi ransum dari perlakuan $\mathrm{R}_{2}, \mathrm{R}_{3}$, dan $\mathrm{R}_{1}$ berbeda sangat nyata $(\mathrm{P}<0,01)$ lebih tinggi dibandingkan perlakuan $\mathrm{R} 0$. Perlakuan tersebut, ternyata dengan penggunaan 10 persen daun pisang dan lama fermentasi 10 hari menghasilkan jumlah konsumsi terbanyak. Konsumsi terbanyak yang dicapai oleh ternak yang mengkonsumsi ransum $\mathrm{R}_{2}$, diduga disebabkan oleh ransum yang mengandung daun pisang terfermentasi selama 10 hari mengalami peningkatan kandungan dan kualitas nutrien (zat gizi) terutama protein yang difermentasi dengan Triohdderrna viride. Fermentasi menyebabkan sejumlah protein, karbohidrat dan lemak dipecah menjadi fraksi yang lebih kecil sehingga percernaan dan penyerapan zat-zat gizi tersebut lebih mudah. Bila data ini dibandingkan dengan daun Pisang tanpa fermentasi (Tabel 1) maka nilai nutrisi hasil fermentasi selama 10 hari lebih tinggi. Hal ini sejalan dengan pendapat Winarno, dkk. (1990), makanan yang mengalami fermentasi mempunyai nilai gizi yang tinggi jika dibandingkan dengan bahan asalnya.

Pengaruh daun pisang yang tidak difermentasi menyebabkan rendahnya konsumsi ransum pada Ro, diduga terutama karena bentuk fisik pakan yang kurang membangkitkan selera makan ternak. Hal ini sesuai dengan pendapat North (1984) bahwa bentuk pakan juga turut mempengaruhi konsumsi ransum. Hasil analisis keragaman tabel menunjukkan bahwa lama fermentasi daun pisang dalam ransum memberikan pengaruh yang sangat nyata $(\mathrm{P}<0.01)$ terhadap hasil pertambahan berat badan.

$$
\text { Hasil uji lanjut Beda Nyata }
$$
Terkecil menunjukkan bahwa pertambahan berat badan perlakuan $R_{2}, R_{3}$, $\mathrm{R}_{1}$, sangat nyata lebih tinggi dari pada perlakuan $\mathrm{R}_{0}$. Pertambahan berat badan perlakuan Ro yang lebih rendah dapat dijelaskan karena rendahnya konsumsi ransum sebagai akibat tidak seimbangnya kandungan protein dan energi metabolis dalam ransum tersebut. Wahju (1988) menyatakan apabila energi dalam ransum berlebihan maka konsumsi ransum menjadi rendah sehingga konsumsi nutrien lain yang diperlukan untuk pertumbuhan optimum atau produksi menjadi rendah dengan demikian akan terjadi sedikit penurunan dalam tingkat pertumbuhan. Selain itu, kandungan serat kasar dalam ransum meningkat pada gilirannya akan mempengaruhi konsumsi dan berat badan. Hal ini disebabkan karena sifat fisik dari serat kasar yaitu sebagai bulk dan juga 
dapat mempercepat transit makanan dalam usus halus. Serat kasar dicerna dengan membutuhkan energi yang tinggi pula, energi tersebut diperoleh dari konsumsi energi dalam ransum yang berasal dari zat makanan (protein, karbohidrat dan lemak), melalui proses lipolistis dalam jaringan adipose. Ini berarti bahwa energy untuk pembentuk lemak tubuh melalui proses lipogenesis menjadi kecil (rendah).

Penggunaan 10 persen daun pisang terfermentasi selama 10 hari dalam ransum yang menghasilkan pertambahan berat badan paling tinggi. Pertumbuhan mempunyai hubungan yang erat dengan jumlah ransum yang dikonsumsi. Pertumbuhan yang cepat seperti yang dimiliki oleh broiler, lebih sensitif terhadap pengaruh tingkat gizi dengan kualitas dan kadar protein yang baik serta energi yang seimbang akan mengakibatkan pertumbuhan yang cepat. Hal ini sejalan dengan pendapat Tillman, $d k k$. (1989) bahwa keseimbangan zat-zat makanan terutama energi dan protein dalam ransum sangat mempengaruhi berat badan dari ternak. Jumlah ransum yang dikonsumsisemakin banyak, makin banyak zat-zat yang masuk ke dalam tubuh sehingga makanan yang dibutuhkan untuk pertumbuhan maksimal bisa terpenuhi.

Berdasarkan sudut pandang nutrisi, pertambahan berat badan $\mathrm{R}_{2}, \mathrm{R}_{3}, \mathrm{R}_{1}$ yang lebih tinggi Ro disebabkan kandungan zatzat makanan dalam ransum yang mengandung daun pisang terfermentasi selama 10 hari dengan level 10 persen, terutama protein dan karbohidrat yang mengalami peningkatan kualitas dan nilai biologis. Peningkatan kualitas dan nilai biologis ini disebabkan oleh kegiatan fermentasi yang dapat dilakukan oleh jamur Trichoderma viride. Jamur ini dikenal juga sebagai jamur selulolitik karena dapat menghasilkan enzim ekstraselular selulase, sehingga dapat menggunakan bahan pakan yang mengandung serat kasar yang tinggi untuk menguraikan selulosa menjadi glukosa (Syamsuriputra, 1983; Rahayu, 1990). Enzim endoglukanase (EG $=\mathrm{CX}$ ) menyerang bagian amorf (tidak beraturan) serat selulosa, membuka jalan bagi kerja enzim selobiohidrolase $(\mathrm{CBH}=$ $\mathrm{Cl})$. Setelah itu, kedua enzim tersebut bekerjasama saling membebaskan serat selobiosa dari serat selulosa. Baik enzim endoglukanase maupun selobiohidrolase tidak mampu memecah selobiosa sehingga diperlukan enzim lain, yaitu b-glukosidase yang menguraikan selobiosa menjadi glukosa (Judoamidjojo, dkk., 1989). Dengan demikian, bahan pakan yang telah mengalami peningkatan kualitas dan nilai biologis diserap oleh tubuh, yang pada gilirannya membantu sintesa jaringan- 
jaringan tubuh dan mempengaruhi pertambahan berat badan.

Hasil analisis keragaman menunjukkan bahwa lama fermentasi tepung daun pisang dalam ransum memberikan pengaruh yang sangat nyata nyata $(\mathrm{P}<0.01$ ) terhadap efisiensi penggunaan ransum. Hasil perbandingan nilai rataan melalui uji lanjut beda nyata terkecil menunjukkan bahwa efisiensi penggunaan ransum perlakuan $R_{2}, R_{3}, R_{1}$ sangat nyata lebih tinggi daripada perlakuan Ro. Tingginya efisiensi penggunaan ransum pada ayam pedaging yang diberikan ransum mengandung daun pisang terfermentasi 10 hari dengan level 10 persen dapat dilihat pada konsumsi ransum yang tinggi mengakibatkan pertambahan berat badan yang tinggi. Hal ini menunjukkan kemampuan biologis ayam pedaging tersebut tinggi dalam arti kemampuan untuk mengubah ransum yang dikonsumsi menjadi suatu produk (pertambahan berat badan) adalah tinggi. Ini sesuai dengan pendapat Wahju (1988) bahwa dalam ransum yang mengandung semua zat-zat makanan yang dibutuhkan, efisiensi penggunaan makanan tergantung pada kandungan energi metabolis dalam ransum tersebut. Ini berarti bahwa daun pisang yang difermentasi selama 10 hari dengan level 10 persen dalam ransum mampu menyediakan zat-zat makanan yang diperlukan dalam keadaan seimbang sebagai hasil dari fermentasi dimana terjadi peningkatan kualitas dan nilai biologis bahan pakan tersebut. Fermentasi menyebabkan sejumlah protein, karbohidrat dan lemak dipecah menjadi asam amino, glukosa dan asam-asam organik sehingga lebih muda dicemah dan diserap dalam usus. Menurut Anggorodi (1985) efisiensi penggunaan makanan menunjukkan kemampuan biologis seekor ternak untuk merubah makanan yang dikonsumsi menjadi suatu produk. Lebih lanjut Anggorodi (1985) menyatakan bahwa secara umum efisiensi penggunaan ransum dipengaruhi oleh faktor konsumsi, daya cerna dan penggunaan zat-zat makanan.

\section{KESIMPULAN}

Berdasarkan hasil penelitian ini dapat disimpulkan bahwa dengan diperbaikinya nilai nutrisi daun pisang maka penggunaan daun pisang terfermentasi selama 10 hari dengan pemberian 10 persen dalam ransum memberikan pengaruh yang baik terhadap efesiensi penggunaan pakan ayam broiler.

\section{DAFTAR PUSTAKA}

Anggorodi, R. 1985. Kemajuan Mutakhir Dalam llmu Hakanan Temak Unggas. Universitas Indonesia. Jakarta. 
Hardjo S. N. S. Indrasti. T. Bantacut. 1989. Dikonversi : Pemanfaatan Limbah Industri Pertanan. Departemen Pendidikan dan Kebudayaan Dir. Jend. Pendidikan Tinggi Pusat Antar Universitas Pangan dan Gizi. Institut Pertanian Bogor.

Harmain. A. E. 1986. Pengaruh Penggunaan Tepung Daun Pisang Sebagai Bahan Makanan Tambahan Dalam Ransum Ayam Petelur Fase Grower. Skripsi. Fakultas Petemakan Universitas Sam Ratulangi. Manado.

Judoamidjojo, M. R., E. G. Sa'id, L. Hartoto. 1989. Biokonversi. Departemen Pendidikan dan Kebudayaan Dir. Jend. Pendidikan Tinggi Pusat Antar Universitas Bioteknologi. Institut Pertanian Bogor.

National Research Council. 1994. Nutrient Requirement Of Poultry. Ninth Revised Ed. National Academy Press. Washington, DC.

North, M. O. 1984. Commercial Chicken Production Manual. 3th Ed. The AVI
Publishing Company, Inc. Westport, Connecticut. New York.

Rahayu, K. 1990. Enzim Mikroba. Proyek Peningkatan Perguruan Tinggi.Universitas Gadjah Mada. Yogyakarta.

Syamsuriputra, A. A. 1979. Pemanfaatan Buangan Pertanian Untuk Makanan Temak Berprotein Tinggi. Team Riset Mahasiswa Departemen Teknik Kimia Institut Teknologi Bandung. Bandung

Tillman A.D., H. Hartadi, S. Reksohadiprodjo, S.Prawirokusumo, S. Lebdosoekojo. 1989. Ilmu Makanan Temak Dasar. Gadjah Mada University Press. Yogyakarta.

Wahju, J. 1988 Ilmu Nutrisi Unggas. Cetakan Retiga. Gadjah Mada University Press Yogyakarta

.Winarno, F. G., dan S. Fardias. 1990. Biofermentasi Dan Biosintesa Protein. Angkasa Bandung. 